\title{
Potensialitas Puisi Bithoqoh Hawiyah Karya Mahmud Darwish: Menilik Politik Kedaulatan Negara Palestina
}

\author{
M. Hafidzulloh S. M., dan Aprinus Salam \\ Universitas Gadjah Mada
}

Corresponding authors.hafidzulloh@mail.ugm.ac.id; aprinus@ugm.ac.id

How to cite this article (in APA Style). Hafidzulloh \& Salam, A. (2021). Potensialitas puisi Bithoqoh hawiyah karya Mahmud Darwish: menilik politik kedaulatan negeri Palestina. Jurnal Pendidikan Babasa dan Sastra, 21(1), 51-64. https://doi.org/10.17509/bs_jpbsp.v21i1.36658

History of article. Received: February 2021; Revised: March 2021; Published: April 2021

\begin{abstract}
Abstrak: Sebuah karya sastra berpotensi memberikan kontribusi nyata untuk meneguhkan kedaulatan suatu Negara-bangsa. Puisi Bithoqoh Hawiyah merupakan karya fenomenal Mahmud Darwish yang mencerminkan identitas kebangsaan dan bentuk representatif warga untuk tetap mempertahankan kedaulatan Negara Palestina akibat invansi Negara Israel. Penelitian ini bertujuan mengungkap potensialitas dalam puisi Bithoqoh Hawiyah Mahmud Darwis. Puisi Bhitoqoh Hawiyah menghadapkan reduksi kehidupan 'politis' warga dalam kedaulatan Negara dengan kemerdekaan Negara yang imajiner. Potensialitas ditransformasikan secara aktual dalam karya sastra sebagai gambaran kehidupan manusia dengan motif untuk berdialektika dengan kenyataan. Kritik puisi Bithoqoh Hawijah dieksplorasi lebih jauh melalui perspektif filsafat politik Giorgio Agamben, yang membentuk konsepsi tentang potensialitas politik warga, negara dan kedaulatannya. Potensialitas dalam puisi Bhitoqoh Hawiyah diasumsikan memiliki dualitas yang koheren dengan impotensialitasnya. Impotensialitas bekerja dalam ranah potensi penangguhan untuk menanggalkan nilai-nilai negatif yang terbingkai dari penjarahan Israel. Karena itu, artikel ini menunjukkan bahwa puisi Bithoqoh Hawiyah merupakan bentuk kritik terhadap berbagai peristiwa sosial-politik yang terjadi antara Palestina dan Israel, dan sebagai pengalaman kolektif warga Palestina untuk mengukuhkan kemerdekaan mereka.
\end{abstract}

Kata kunci: potensialitas; puisi bithoqoh hawiyab; kedaulatan; impotensialitas; penangguh

\section{The Potentiality of Poetry Bithoqoh Hawiyah by Mahmud Darwish: Observing the Sovereignity Politics of the State of Palestine}

\begin{abstract}
A literary work has the potential to make a real contribution to affirming the sovereignty of a nation-state. The poem Bithoqoh Hawiyah is a phenomenal work of Mahmud Darwish that reflects national identity and a representative form of citizens to maintain the sovereignty of the Palestinian State due to the invasion of the State of Israel. This study aims to reveal the potentiality in Mahmud Darwis' poem Bithoqoh Hawiyah. The poem Bhitoqoh Hawiyah confronts the reduction of the 'political' life of citizens within the sovereignty of the State with imaginary State independence. Potentiality is transformed in literary works as a picture of human life with a motive for dialectic with reality. The criticism of the poem Bithoqoh Hawiyah is further explored through the perspective of Giorgio Agamben's political philosophy, which forms a conception of the political potentiality of citizens, the state, and their sovereignty. Potentiality in the poem Bithoqoh Hawiyah is assumed to have a duality coherent with its impotentiality. Impotentiality operates in the realm of potential suspension to strip the negative values framed from Israeli plunder. Therefore, this article shows that the poem Bithoqoh Hawiyab is a form of criticism of the various socio-political events that occurred between Palestine and Israel, and as a collective experience of Palestinians to strengthen their independence.
\end{abstract}

Keywords: potentiality; bithoqoh hawiyah; sovereignty; impotentiality; suspension 


\section{Pendahuluan}

Puisi Bithoqoh Hawiyah merupakan salah satu karya Mahmoud Darwish yang menggambarkan konflik antara PalestinaIsrael. Mahmoud Darwish merupakan sastrawan Timur Tengah yang kerap melakukan kritik terhadap penjarahan sebagian wilayah Palestina melalui karya sastranya. Darwis mengimajinasikan masa depan bangsa Palestina yang mengalami imperialisme dari kelompok Zionisme. Bithoqob Hawiyah difungsikan sebagai potensialitas. Dalam pandangan Aristotelian, potensialitas dipahami sebagai suatu kemungkinan yang bersifat metafisik.

Karya sastra, dalam pandangan Agamben, merupakan narasi atau literatur yang mampu membuka dan membongkar hal-hal yang bersifat metafisik dari fenomena empirik yang terjadi dalam struktur masyarakat tertentu. Agamben melihat karya sastra tidak hanya menyuguhkan narasi tanpa alasan tertentu. Menurutnya, narasi yang tertuang dalam sastra tidak hanya bersifat ilustratif, bahwa ia mampu melampaui narasi tersebut merupakan hal paling fundamental untuk memahami makna dari proses interpretasi tekstual dari karya sastra (Watkin, 2010).

Puisi Bithoqoh Hawiyah berfungsi sebagai potensialitas yang menghadirkan imajinasi terbentuknya kedaulatan negara Palestina khususnya, dan masyarakat timur tengah umumnya. Mahmoud Darwish merupakan sastrawan Timur Tengah yang kerap melakukan kritik terhadap penjarahan sebagian wilayah Palestina melalui karya sastranya. Selain itu, tulisan ini akan membahas karya sastra sebagai potensialitas yang mampu bergerak dalam ranah aktualisasi dalam narasi di dalamnya.
Sebagai potensialitas, karya sastra digunakan untuk melihat lebih lanjut aspek-aspek yang dinarasikan dan ditawarkan, baik dari pengarang, maupun karya itu sendiri yang dikontekstualisasikan dengan situasi sosial. Oleh karena itu, dalam penelitian ini akan mengeksplorasi puisi Bithoqob Hawiyah sebagai potensialitas terhadap otoritas Palestina sebagai Negara merdeka dalam perspektif Giorgio Agamben.

Kedaulatan negara yang diperoleh melalui proses pembebasan dari wacana penindasan maupun inovasi dari pihak eksternal selama ini dipahami sebagai keadaan yang mampu membawa negarabangsa ke arah yang lebih progresif. Keadaan demikian tidak berlaku bagi warga negara Palestina yang secara hukum mereka telah terbebas dari berbagai unsur eksternal dan merdeka secara konstitusional. Lebih jauh lagi, subjek utama dalam proses membentuk kedaulatan negara bersumber dari kekuatan-pembentuk-konstitusi, yang dalam hal ini adalah warga negara. Karena itu, warga negara Palestina yang memiliki hak konstitusional dalam dekade akhir ini tidak lagi merasakan sebagai subjek penentu terhadap kekuatan kedaulatankonstitusional. Sebagai warga negara, mereka tidak lagi sebagai entitas yang murni serta keberadaannya selalu dikaitkan dengan aturan-aturan yang berasal dari eksternal. Faktor eksternal yang menelanjangi warga palestina sebagai kekuatan-pembentuk-konstitusi murni direduksi oleh wacana-wacana dan metanarasi mengenai perebutan wilayah yang diklaim sebagai warisan peradaban antara Islam dan Yahudi Zionisme.

Konflik yang terjadi antara Palestina dan Israel belum menemukan jalan keluar 
yang mampu mengcover antar keduanya. Apabila dilacak dari aspek historisnya, konflik kedua negara tersebut dilatarbelakangi karena saling klaim wilayah yang diyakini sebagai warisan peradaban dalam lanskap keagamaan. Di satu sisi, perebutan wilayah tersebut, dari kacamata Israel yang berpaham Zionisme, diyakini sebagai tanah menjanjikan (promise island) yang diwariskan oleh leluhur mereka. Sedangkan bagi warga Palestina, wilayah Yerusalem yang diperebutkan itu terdapat warisan peradaban Islam yang hingga saat ini bangunan warisan tersebut masih eksis, yakni Masjid Al-Aqsha di sisi lain. Lebih jauh lagi, semangat keagamaan inilah kemudian menjadikan kedua negara tersebut membuat narasi-narasi yang mengacu pada aspek partikular, yakni persoalan identitas.

Hal tersebut bisa diketahui bagaimana semangat keagamaan dari kalangan YahudiZionisme yang sebagian besar keberadaan mereka tersebar di negara-negara Eropa dan Amerika merasa terpanggil untuk menduduki wilayah yang diklaim sebagai warisan peradaban mereka. Perpindahan demikian menyebabkan penjarahan sebagian besar negara Palestina untuk mendirikan tempat tinggal baru bagi kaum urban tersebut. Kemerdekaan warga dan negara Palestina tidak bisa diperoleh secara utuh, selalu dalam kondisi yang membahayakan karena invasi masih terjadi secara kontinyu (Jung, 2004).

Fenomena tersebut mengundang banyak respon dari berbagai kalangan dengan motif pembelaan terhadap Palestina, dan salah satu bentuk respon tersebut dimediasi dalam bentuk karya sastra, baik dari warga Palestina sendiri maupun dari pihak luar. Dengan sastra sebagai mediatornya, suara-suara yang terbungkam akibat invasi tersebut bisa tersalurkan melalui karya sastra, dan karena itu, karya sastra mampu melukiskan bentuk-bentuk imajinatif yang mengarahkan pembaca untuk memahami fakta empirik dari fenomena sosial. Fungsi sastra sebagai reopening the world membuka dialektika diskursif yang menempati posisi penting. Dalam struktur kebudayaan Arab, sastra memiliki fungsi sosial yang sifatnya taken for granted antara pengarang dan pembaca, serta sebagai mediator penting antara keduanya (Smart, 1996), (Dardiri, 2011). Hal ini menandakan bahwa sastra merupakan aset dan elemen penting yang mendokumentasikan kebudayaan suatu bangsa. (Hitti, 2002) menjelaskan bahwa masyarkat Arab adalah bangsa yang sangat menjunjung tinggi kesusasteraan. Sastra digunakan sebagai bentuk kritik dan menyingkap serangkaian konflik yang melanda kawasan Timur Tengah. Bahwa sastra berfungsi untuk menyingkap segala kesenjangan sosial yang dialami manusia (Agamben, 1999).

Konsep dasar pemikiran Agamben yang mengelaborasi dua gagasan mengenai totalitarian Hanna Arendt dan bio power Foucault yang digunakan untuk menelisik lebih jauh peranan kedaulatan Negara untuk mengukuhkan internalnya. Dalam pandangan Agamben, keberlangsungan kedaulatan Negara tidak lepas dari konsep totalitarian dan dari hal ini kemudian eksistensi manusia diserahkan sepenuhnya kepada hukum, sejarah dan kekuatan alam. Dengan begitu, kehidupan manusia menjadi terkontrol oleh sesuatu yang disebut sebagai bio power. Pada titik ini konsep bio power bekerja yang kemudian oleh Agamben disebut dengan bio politik (Agamben, 1998) konsepsi mengenai biopolitik merupakan upaya kekuatan- 
pelaksana-konstitusi untuk mengatur kompleksitas kehidupan warga Negara. (Sudibyo, 2019) menjelaskan konsep biopolitik merujuk pada keadaan atau tahapan di mana individu telah terintegrasi dalam kolektivitas sosial atau asosiasi politik. Dan karena itu, secara esensial, eksistensi warga negara bisa direpresentasikan dengan sifatsifat politis (Lechte, 2013).

Lebih jauh lagi dalam perspektif Agamben, kondisi alamiah manusia melebur ke dalam zona yang politis. Norma sosial yang basisnya nilai etis akan tergerus secara politis sehingga diri manusia mengalami ketelanjangan (bare life). Momen seperti ini memiliki impact yang mengakar kuat pada seluruh lapisan masyarakat. Sebagai dampaknya, nilai etis akan beralih menjadi nilai politis, yang akhirnya setiap tindakan manusia merupakan tindakan politis (Agamben, 1998) (Ritzer \& Goodman, 2001), (Foucault, 2007) menggunakan term ini sebagai bentuk kekuasaan yang mengatur kehidupan manusia melalui apparatus, keberadaan apparatus hampir tidak terlihat, namun strukturnya tertata rapi dan cair. Apparatus digunakan untuk membentuk, mengontrol wacana dalam bentuk metanarasi yang distrukturasikan ke dalam kehidupan warga negara (Agamben, 2020). Hal yang penting dari keberadaan kedaulatan dan kelanggengan politik negara modern ialah keberadaan apparatus (Agamben, 2020). Meskipun rezim dan aparatus berganti, kedaulatan akan tetap langgeng. Masalahnya, apabila kedaulatan terusik, maka negara akan mengukuhkan hukum dan menyatakan status kedaruratan (state of exception).

Terjadinya keadaan-darurat pada suatu negara membuatnya melakukan mekanisme pengukuhan hukum serta melegalkan segala tindakan dengan tujuan pertahanan nasional, menjaga kedaulatan negara. Pada waktu yang sama, warga negara mengalami ketelanjangan hidup dan ketelanjangan itu membuatnya keluar dari norma hukum. Karena pengeksklusian tersebut warga negara berada di luar hukum, sehingga hidupnya berada pada momen pengecualian dan rentan akan kekerasan. Kelompok atau warga negara tersebut disebut sebagai homosacer (Agamben, 1998) menggunakan istilah bomo sacer merujuk pada suatu tatanan dan sistematik hukum yang digunakan pada era Romawi kuno. Penggunaan istilah ini ditujukan kepada warga Negara yang berada di luar hukum. Artinya status homo sacer yang disematkan pada warga dan memungkinkan dirinya diberlakukan secara radikal. Dengan status tersebut warga negara dikeluarkan dari struktur masyarakat dan boleh dihukum namun tidak boleh dikorbankan (Agamben, 1998).

Potensialitas merupakan kunci dari pemikiran Agamben yang berfungsi untuk mengkonfigurasi kompleksitas kehidupan manusia dalam karya sastra. Demikian halnya dengan fungsi sastra itu sendiri, yang dimaksud dengan potensialitas adalah menyuguhkan berbagai alur kehidupan sosial yang kemudian diatur sedemikian rupa dalam karya. Harapan dari yang potensial adalah untuk memberikan gambaran antara yang memiliki potensialitas maupun yang impotensialitas, bahwa karya sastra merupakan media untuk pembebasan (liberation) terhadap apapun yang menyertai kondisi terciptanya karya tersebut (Agamben, 2020). Oleh karena itu potensialitas bekerja sebagai tindakan yang mampu melampaui domaindomain yang bisa diterobos (Ross, 2008).

Potensialitas berhubungan dengan aktualitas tidak dalam gerak realisasi diri, tetapi dalam gerak penangguhan diri, tidak menjadi atau melakukan sesuatu (Sudibyo, 2019: 126). Dalam karya sastra, potensialitas seharusnya membuka dimensi 
ontologi nilai-nilai kemanusiaan serta menelaah konsepsi nonpotensi ke dalam potensialitas. Art should be the revelation of pure potentiality, not an object for consumption and certainly not a "product" detached from the revelation of the open (Ross, 2008). Kemampuan sastra sebagai yang potensialitas mampu menyuguhkan gambaran realita jauh melampaui kondisi dan situasi yang non potensial, menyuguhkan realitas faktual berdasarkan pengalaman empirik tanpa adanya tendensi apapun (Agamben, 1995). Isi dan bentuk karya fiksi digunakan untuk menggambarkan kondisi yang akan terjadi, menjadi mediator imajinasi pembaca, dan bagaimana realita kedepannya bisa diinterpretasi (Agamben \& Heller-Roazen, 1999); (Watkin, 2010). Sejalan dengan hal itu, interpretasi merupakan aktivitas yang dilimpahkan terhadap pembaca secara penuh untuk mengetahui makna yang tersirat dari karya sastra. Tanaka menjelaskan bahwa pembaca merupakan bagian dari aspek makro sastra yang memiliki hubungan kausalitas dan simbiosa mutualistis terhadap karya sastra (Tanaka, 1976).

Penelitian yang terkait dengan kesamaan objek material pernah dilakukan oleh pertama, Sepriyanti Handayani Putri berjudul "Tema Patriotisme dalam Tiga Puisi Karya Mahmoud Darwish" (2010). Dari penelitian ini, puisi Bithoqoh Hawiyah dianalisis dalam perspektif unsur-unsur intrinsik yang terdapat di dalamnya, antara lain dari segi tipografi, diksi, imaji, majas dan simbol dalam puisi; kedua, Tanti Yuliansih yang berjudul "Imageri dalam Puisi Bithaqah Hawiyyah Karya Mahmoud Darwisy": Kajian Stilistika (2016). Temuan dari penelitian ini menunjukkan bahwasannya pengarang menggunakan gaya bahasa yang lugas dengan menggambarkan kondisi tanah airnya. Gaya tersebut dilakukan untuk mengajak pembaca merenungi konstelasi dan dinamika sosial-politik yang berkelindan saat itu; ketiga, Insiyyah Istibsyarotul (2017) dengan tema "Gaya Bahasa Bayan dalam Puisi Bithoqoh Huwiyyah Karya Mahmoud Darwish". Penelitian ini menggunakan perspektif ilmu al-Balaghah yang berfokus pada penggunaan diksi atau gaya bahasanya.

Penelitian selanjutnya pernah dilakukan oleh Tri Desi Ambarwati dengan judul "Syair Bithoqoh Huwaiyah Karya Mahmud Darwish: Pendekatan Semiotika Michael Rifaterre" (2018). Temuan dari penelitian ini menunjukkan adanya ketidaklangsungan ekspresi yang berdampak pada pergantian makna utama isi puisi; Reza Desmita dan Kurnia Ningsih dengan tema "Holding The Existence in Five Poems by Mahmoud Darwish" (2019). Penelitian ini menggunakan konsep mitos dari Carl Gustav Jung dengan hasil bahwa terdapat ancaman terhadap kebudayaan warga Palestina sehingga mereka merasa terpanggil untuk menyerukan kebebasan dan mempertahankan tanah airnya; dan, Hidayatun Ulfa "Hermeneutika Puisi Bitaqah Huwiyyah dalam Antologi Auraquz-Zaitun Karya Mahmud Darwisy" (2020) dengan hasil penelitian bahwa puisi ini sebagai bentuk protes terhadap pelbagai bentuk penjarahan geografis yang dialami oleh warga Palestina. Dari beberapa penelitian tersebut, belum ditemukan penelitian yang menggunakan objek formal teori sosiologi sastra perspektif Giorgio Agamben dalam menganalisis puisi Bithoqoh Hawiyah. 
Dari uraian di atas, artikel ini merumuskan beberapa masalah yang akan dibahas. Pertama, bagaimana karya sastra sebagai potensialitas. Mengingat bahwa karya sastra merupakan gambaran dunia atau dunia imajiner dari situasi dan kondisi sosial. Kedua, mengapa impotensialitas karya sastra inheren dengan potensialitas. Bahwa impotensialitas merupakan aspek yang mampu membuka interpretasi terhadap dimensi inklusivitas kondisi sosial yang terekam dalam karya sastra.

\section{Metode}

Metode dalam proses penelitian adalah rangkaian proses untuk memperoleh pengetahuan tentang keberadaan dan kodrat objek penelitian (Faruk, 2012). Dalam penelitian ini, data akan diproses dalam dua tahap, yakni pengumpulan data, berupa satuan tekstual yang berhubungan dengan teori filsafat politik, dan analisis data. Sedangkan, kodrat objek penelitian yang berupa satuan tekstual bersumber dari objek material tersebut digunakan dalam penelitian ini adalah puisi Bithoqob Hawiyah karya Mahmoud Darwish dijadikan sebagai sumber primer. Kemudian, berbagai literatur, buku maupun makalah ilmiah penunjang penelitian dimanfaatkan sebagai data sekunder yang telah divalidasi dengan sumber data primer.

Langkah selanjutnya adalah analisis data yang merupakan bentuk dari perpanjangan pikiran manusia karena esensinya tahap ini bertujuan untuk mencari hubungan antardata yang tidak pernah dinyatakan sendiri oleh data yang bersangkutan (Faruk, 2012). Setelah variabel-variabel penelitian telah disinkronisasi dalam proses pengumpulan data, selanjutnya akan dicari hubungan kolaboratif antar keduanya. Dari data-data tekstual yang berupa satuan linguistik, kata dan bait dari objek material dan selanjutnya akan dilakukan identifikasi sesuai dengan tujuan utama artikel ini yakni potensialitas murni, juga bertindak sebagai impotensialitas kontemplasi bagi warganegara Palestina dalam perspektif Giorgio Agamben.

\section{Hasil dan Pembahasan}

Puisi Bithoqoh Hawiyah menjadi salah satu karya sastra dalam bentuk puisi yang hadir di tengah masyarakat Arab, khususnya Palestina, juga berfungsi sebagai potensialitas yang menghadirkan imajinasi terbentuknya kedaulatan negara Palestina khususnya, dan masyarakat timur tengah umumnya. Secara garis besar, isi puisi ini adalah bentuk gambaran dari konflik antara Palestina-Israel yang disampaikan secara implisit, juga mampu membangkitkan imajinasi pembaca terkait masa depan bangsa Palestina yang terus mengalami imperialisme dari kelompok Zionisme. Subjektivitas pengarang pada puisi ini juga memperlihatkan bagaimana menjaga identitas nasionalisme Arab, dan menolak upaya invansi Israel.

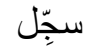 \\ Catatlah

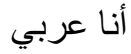

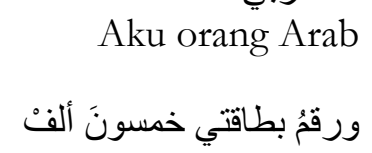

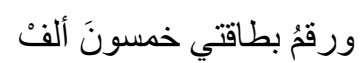

Dan kartu identitasku bernomor 50.000

$$
\text { و أطفالي ثمانيةٌ }
$$

Dan aku punya delapan anak

$$
\text { وتاسعهُم.. سيأتي بعدَ صيفْ! }
$$

Yang kesembilan akan lahir setelah musim

panas

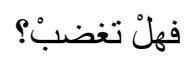

Apakah kau marah? 
Pada awal bait puisi ini menggambarkan bagaimana konstruksi identitas kewarganegaraan yang juga menjadi simbol pribadinya menjadi manusia dalam struktur kenegaraan. Nomor identitas yang ada pada bait di atas secara eksplisit menandakan pengarang juga sebagai warga negara Palestina yang memiliki legalitas hukum. Tentunya legalitas ini tidak hanya berlaku pada dirinya sendiri, juga terhadap garis keturunan yang seharusnya memiliki hak sebagai warga negara. "yang kesembilan akan lahir setelah musim panas" artinya ada harapan dari pengarang agar keberadaannya selalu diakui secara hukum. Yang menjadi kontradiksi dalam kutipan di atas secara eksplisit menyerukan "apakah kau marah?" adalah bentuk kritik terhadap kondisi Palestina saat ini yang tengah dilanda konflik, baik yang dikarenakan faktor internal maupun eksternal. Sebagai entitas tunggal yang memiliki hak hidup, berekspresi dengan statusnya sebagai entitas berakal. Bahwa segalanya tidak akan mudah dicapai, sebab yang menjadi tantangannya adalah bagaimana mempertahankan seluruh identitas tidak lagi terfragmentasi, terpecah bahkan tercecer dalam beberapa bagian. Tentu saja kondisi demikian bertolak belakang dari aspek historisnya.

Mahmoud Darwish dikenal sebagai sosok sastrawan ulung yang gemar menulis puisi serta membacakan dengan nada berapi-api. Hampir keseluruhan puisi yang ia tulis memiliki ciri khas yang identik dengan perlawanan dan dominasi Israel terhadap tanah airnya, Palestina. Suatu kawasan yang disakralkan oleh dua agama besar, yakni Islam dan Yahudi. Karena hal ini juga yang menjadi dasar kemunculan konflik, serta mengundang respon warga dunia yang mempertanyakan kedaulatan Palestina sebagai negara yang sah secara konstitusional. Adapun asumsi dasar konflik kedua agama ini diawali dengan keyakinan masing-masing agama yang saling klaim bahwa Palestina adalah peninggalan nenek moyang agama Yahudi, di sisi lain terdapatnya masjid Al-Aqsha yang menjadi arah kiblat pertama bagi seluruh umat muslim. Klaim pembenaran dari kedua belah pihak menunjukkan adanya memori kolektif yang saling merasa paling benar. Bahwa ingatan kolektif Israel berpegang pada narasi Holocaust/Shoah, bangsa Palestina harus menanggung narasi al-Nakba, penganiayaan dan pengusiran dari tanah mereka (Epafras, n.d.).

\section{سجِّل \\ Catatlah

$$
\text { أنا عربي }
$$

Aku orang Arab

و أعملُ مع رفاقي الكدح في محجز

Aku bekerja dengan teman pekerja mencari nafkah di pertambangan

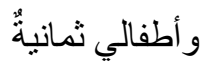

Aku punya delapan anak

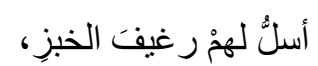

Aku memberi mereka roti

و الأثوابَ و الدفتزْ
Serta pakaian dan buku-buku

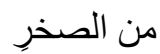

Dari batu

و لا أتوسَّلُ الصدقاتِ من بابِكْ

Dan aku tidak mengemis di depan pintumu

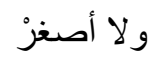

Dan aku juga tidak merasa rendah

$$
\text { أمامَ بلاطِ أعتابكَْ }
$$

Di depan teras rumahmu aku mencelamu

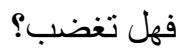

Apakah kau marah?

Pada kutipan di atas pengarang menjelaskan bagaimana ia menjadi subjek yang secara tidak langsung masuk dalam ranah biopolitik, segala aktivitas 
kehidupannya menyesuaikan dengan kehendak yang kuasa. Ia dan kolega bekerja untuk menghidupi keluarga bentuk metafora dari seluruh rakyat Palestina yang segalanya dikontrol oleh Israel. Sikap pemerintah yang sejatinya bertugas untuk memberikan hak hidup bagi setiap warga negara perlu ditinjau kembali. Karena dengan memberikan hasil pekerjaan yang berupa "batu" adalah sesuatu yang memerlukan penjelasan lebih jauh. Batu merupakan kiasan dari sumber daya alam, dalam hal ini adalah minyak yang melimpah ruah di timur tengah, yang telah diasosiasikan oleh kepentingan kekuasaan. Keterlibatan kekuasaan dalam kontrol demikian tidak terlepas dari campur tangan eksternal dalam konstruksi wacana eksploitasi. Penciptaan puisi ini merupakan bentuk perlawanan baik dari sisi pengarang, dan pembaca untuk menyerap makna puisi di sisi lainnya, serta menanamkan konstruksi persatuan Arab sebagai norma dan memori kolektif yang seharusnya diwariskan ke seluruh keturunan mereka (Kramer, 1993).

Dengan dalih memerangi kebiadaban Saddam dan kerasnya pemerintahan Taliban, intervensi Amerika kepada kedua Negara tersebut dipandang sah, yakni demi penyelamatan kemanusiaan (Burdah et al., 2008). Dalam praktiknya, Amerika tidak segan untuk menjadikan banyaknya korban jiwa akibat misi ini. Dengan mengatasnamakan HAM, Amerika malah menyalahi aturan itu sendiri. Dampak yang ditimbulkan adalah banyaknya para demonstran yang meninggal dunia, sampai pada penggulingan pemerintahan dan sampai saat ini Negara-negara tersebut tidak lekang dari konflik. Dengan demikian sesuai dengan pendapat Arendt, menurutnya, keterkaitan antara konsep hak manusia (the right of man) dan negara-bangsa (nation-state) ini bersifat paradoks, karena dalam praktiknya eksklusi akan selalu muncul dalam bingkai gerakan HAM. Dalam pengamatan Arendt, konsepsi manusia sebagai makhluk yang sacral, luhur dan setara telah memudar, yang ada hanyalah bentuk fisik keadaan manusia yang telah terkontaminasi dan melebur dalam kehidupan politik. Ambivalensi ini yang dipandang sebagai proses pendisiplinan dan normalisasi yang secara langsung mencabut hak asasi manusia yang melekat pada semua orang (Agamben, 1998).

"Dan aku tidak mengemis di depan pintumu" menggambarkan bagaimana kehidupan aku (bangsa Arab) telah direduksi eksistensinya dalam kehidupan sebagai warga negara yang memiliki hak asasi dalam kehidupannya. Karena reduksi tersebut, kebebasan sebagai individu tidak lagi melekat bersamanya. Sindiran terhadap "pintumu" adalah bentuk alegori daripada pendirian wilayah Israel. Hal ini terbukti sejak tahun 1940-1948 Yahudi berhasil menguasai 270 hektar wilayah Palestina, dan dengan 73 pendirian pemukiman baru (Saleh, 2002).

"Tidak akan mengemis di depan rumah" merupakan upaya pengarang untuk membangkitkan semangat persatuan Arab agar tidak lagi tertindas oleh kepentingan global yang berusaha menjadikan wilayah Arab bercerai-berai. Kutipan bait tersebut juga membuka imajinasi pembaca agar mampu berkontemplasi dengan kondisi saat ini. Karena dengan demikian juga dimungkinkan apa yang akan terjadi di masa depan sesuai dengan cita-cita luhur bangsa Arab, serta tidak tersulut api provokasi para misionaris Amerika. Pengarang, dalam hal ini, bertujuan untuk menyadarkan seluruh bangsa Arab agar tidak lagi sibuk dengan konflik. Dengan demikian bagaimana potensi bahasa dalam karya sastra mampu mempengaruhi pembaca dan sebagai media mengaktualisasikan segala aktifitas, dengan motif agar realita kedepan melampaui dan memaknai keterbukaan interpretasi dari karya sastra. Hal yang sama harus dikatakan tentang potensi konstitutif bahasa: seperti semua potensi, ia tidak dihilangkan melainkan dipenuhi dan diselesaikan dalam perjalanan menuju aktualitas. Setiap ucapan, kata hanyalah 
cara potensi bahasa memutuskan sendiri, dengan demikian, menjadi aktualitas (Agamben \& Heller-Roazen, 1999).

Karya sastra bukan hanya menjadi karya fiksi belaka, melainkan juga mampu membuka pandangan dunia mengenai sosial yang tertutup oleh kekuasaan. Bagi Agamben, hal ini adalah tugas dan fungsi yang sifatnya esensial dalam definisi karya sastra. Sastra dipandang memiliki keistimewaan untuk menguak segala aktivitas manusia yang telah terkontaminasi dalam kehidupan politik, sehingga keberadaan manusia tidak lepas dari tindakan politis pemerintah. Ketika politik menjadi makna yang tidak terbatas (means without ends) merupakan momentum dimana segala aktivitas manusia mampu dimanipulasi dalam peraturan yang diidealkan menurut kekuasaan. Di sinilah poin utama Agamben mengani potensialitas manusia sebagai entitas yang utuh dan tidak diarahkan oleh kapasitas partikular atau kriteria-kriteria tindakan (Sudibyo, 2019).

"Dan aku juga tidak merasa rendah" mengilustrasikan bagaimana identitas nasional adalah hal yang tidak bisa diganti dengan apapun. Kalimat itu dinarasikan dalam puisi ini adalah upaya pengarang untuk menentukan masa depan orang Arab, bahwa mereka memiliki harta yang tidak bisa ditukar apalagi direduksi oleh kepentingan eksternal. Hal ini juga membuka potensi bagi orang Palestina untuk melampaui struktur kehidupan yang dikonstruksi oleh AS-Israel. Potensialitas dikonstruk pada warga Palestina untuk tetap menolak invansi Israel, sehingga status negara yang merdeka dimaknai secara total. Keterbukaan yang berpotensi menghadirkan dimensi nasionalis dan humanis ini menegasikan penjarahan Israel dan berfungsi sebagai aktualitas dalam gerak realitas. Oleh karena itu, sebagai potensialitas, karya sastra akan membuka dimensi-dimensi ruang dan mengkonstruksinya sesuai dengan nilai humanisme. Menurutnya, manusia bukanlah suatu entitas yang hanya mampu di investigasi secara politik, atau biopolitik. Sebaliknya, manusia ialah suatu entitas tertentu yang dinamis, bahwa manusia selalu memproduksi sesuatu untuk pribadinya dan berpotensi memiliki banyak ruang murray.

\section{Impotensialitas: Kontemplasi Warga Palestina dan Persatuan Arab.}

Asumsi dasar mengenai impotensialitas dalam perspektif Agamben bukan berarti menihilkan keberadaan potensi untuk bertindak dalam aktualisasinya. Namun titik utama diskursus demikian adalah untuk mengkolaborasikan potensialitas tersebut secara koheren terdapat impotensialitas. Inklusivitas dari potensialitas tersebut mengindikasikan kemampuan untuk tidak menjadi, tidak bertindak sesuai dengan kemampuan. Bahwa sastra tidak hanya berkutat pada persoalan estetika dan otonom, sastra merupakan entitas yang inklusif terhadap konteks sosial yang melatarbelakangi keberadaannya. Dimensi impotensialitas puisi ini menunjukkan adanya determinasi dekonstruktif yang bertujuan untuk menelanjangi suatu kondisi yang dianggap natural. Dengan kata lain bahwa impotensialitas bukan berarti menghancurkan tatanan potensial, namun akan berjalan secara beriringan dan strukturasi tatanan baru.

Campur tangan Amerika dan beberapa negara lain dalam konflik antara Israel-Palestina membuat dunia tertarik untuk mengkajinya. Kompleksitas permasalah yang melanda kedua negara ini juga mengundang simpati warga dunia untuk ikut serta dalam mengupayakan perdamaian agar konflik bisa segera diakhiri. Seperti yang telah dijelaskan di atas, bahwa dengan campur tangan Amerika terhadap beberapa konflik ini juga mengandung yang impotensial. Agamben menjelaskan dalam setiap potensialitas juga berkesempatan menjadi yang impotensial (Agamben \& Heller-Roazen, 1999). 
Dengan kata lain impotensialitas ini berfungsi sebagai rambu-rambu untuk tidak bertindak. Sebagai negara adidaya, Amerika berpotensi mencengkeram dunia dengan segala bentuk gerakan geopolitiknya, namun juga menjadi gerakan yang impotensial apabila dunia menyadari akan bahaya yang ditimbulkan dari gerakan geopolitik Amerika itu sendiri. Tindakan demikian menjelaskan bahwa diskriminasi Israel terhadap Palestina bukan diatasi oleh tatanan tertentu, yakni peranan Amerika, melainkan dengan instrumen geopolitik tersebut menjadi logika bekerja untuk mengakuisisi wilayah Palestina.

$$
\text { صَبورُ في بلادٍ كلٌ ما فيها }
$$

Yang tetap sabar di sebuh negeri dengan segala hal di dialamnya

$$
\begin{aligned}
& \text { ولونُ الثُعِر.. فحميٌّ } \\
& \text { Warna rambutku hitam legam } \\
& \text { ولونُ العينِ.. بنيٌّ } \\
& \text { وميزاتي: } \\
& \text { وكفّي صلبةُ كالصخر }
\end{aligned}
$$

Dan memiliki telapak tangan sekeras batu

$$
\text { (محمود درويش: 75-75) }
$$

Dengan menggambarkan identitasnya sebagai orang Arab, hal ini digunakan untuk menyadarkan seluruh bangsa Arab agar memiliki rasa empati dan sepenanggungan untuk bersatu dan mengakhiri semua konflik yang sedang terjadi. Lebih khusus lagi, karena dengan penyebutan identitas tersebut ditujukan kepada seluruh warga Palestina agar mampu menghalau invansi Israel di wilayah mereka. Karena dengan menyebutkan karakteristik bangsa Arab, pengarang mengharapkan adanya gerakan responsif untuk menghalau berbagai gerakan yang mengancam kedaulatan negara Palestina. Konspirasi AS-Israel menduduki wilayah Palestina selain kepentingan keagamaan juga kepentingan ekonomi global, sumber daya alam yang melimpah akan menjadi milik Amerika apabila berhasil menguasainya.

Adapun tujuan pendudukan Zionisme terhadap Palestina dihasilkan pada kongres pertama kalinya yang dipimpin oleh Theodor Herzl pada tahun 1895 di kota Basel Switzerland. Dari kongres ini menghasilkan beberapa tujuan, diantaranya adalah Palestina dipandang sebagai tanah air kelompok Zionisme dan Palestina adalah tanah suci bagi agama Yahudi (Noor, 2014). Akibatnya, konflik antar kedua Negara ini tidak lagi sekedar perebutan wilayah tetapi pertahanan atas apa yang yang telah direbut dengan berbagai cara sehingga pihak Israel melakukan aksi okupasi. Semua warga negara Palestina yang memiliki hak untuk menjadi warga negara Palestina telah diasosiasikan pada kepentingan global, segala aktifitas Palestina tidak luput dari kungkungan Israel. Meleburnya zoe dalam bios yang diasosiasikan dalam bentuk kepentingan internasional, warga Palestina seperti menjadi warga yang di-homosacerkan.

Bisa dikatakan semua identitas nasional bangsa Arab menjadi sesuatu yang memiliki potensi bersatu di satu sisi, namun di sisi lain karena ini juga jamak bangsa Arab yang terlalu fanatik terhadap konstruksi ruang dan teritori yang diwarisi oleh bangsa kolonial. Dari sini yang menjadi potensialitas adalah persamaan identitas nasional Arab, dan dari identitas itu pula yang menjadi impotensialitas. Yang menjadi impotensialitas adalah karena faktor kewilayahan dan sektarian internal Arab. Oleh karena itu bagaimana dengan identitas nasional Arab mampu diorientasikan dengan fungsinya dan menjadikannya sebagai instrumen persaudaraan Arab.

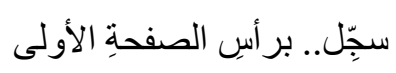

Catatlah sebagai judul di halaman utama أنا لا أكرهُ الناسَ Aku tidak membenci manusia ولا أسطو على أحدٍ Dan juga tidak melanggar apapun 
ولكنّي.. إذا ما جعتُ

Akan tetapi jika aku lapar

آكلُ لحمَ مغتصبي

Daging rampasan akan menjadi makananku

$$
\text { حذارِ.. حذارِ.. من جوعي }
$$

Berhati-hatilah dengan kelaparanku

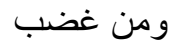

Dan dengan kemarahanku

Kutipan di atas menjelaskan bahwa dengan kesewenang-wenangan Israel melakukan gerakan invasi akan membawa efek buruk terhadap warga negara Palestina. Bentuk perlawanan yang dinarasikan pengarang pada kutipan di atas menunjukkan bagaimana respon pengarang dalam memperjuangkan haknya sebagai warga negara Palestina. Konstruksi potensialitas yang terdapat pada kutipan di atas adalah dengan menggambarkan realitas bangsa Arab. Aktualisasi dan penggambaran dalam karya sastra adalah fungsi sastra sebagai gambaran bagaimana untuk mengaktualisasikan realita. Dengan kata lain adanya potensialitas juga mengkonstruk impotensialitas, dengan motif aktualisasi dalam bentuk fiksi. Adapun impotensial dalam kutipan diatas adalah bagaimana konstruksi potensial terbentuk dari dan inheren dalam impotensial. Apabila seluruh rakyat Palestina dan umumnya seluruh bangsa Arab memiliki potensi mengakhiri rangkaian konflik, maka yang impotensial adalah bagaimana konstruksi potensial itu tidak dan atau belum direalisasikan secara aktual. Karena dengan demikian tindakan yang akan dioperasikan oleh warga negara akan selalu memiliki orientasi yang lebih baik. Oleh karena itu, apabila impotensialitas menjadi orientasi, harapan untuk menghindari kejadian kehidupan telanjang akan dapat diminimalisir.

\section{Keberadaan Puisi Bithoqoh Hawiyah: Sebagai Instrumen Resistensi.}

Keberadaan karya sastra tidak bisa dilepaskan dari faktor eksternal yang berkelindan dengan keberadaan pengarang untuk memaknai pengalamannya untuk dituangkan dalam karya sastra. Karena itu, keberadaan karya merupakan artikulasi pengarang untuk memaknai gejala sosial yang tengah dialaminya. Senada dengan hal tersebut, puisi Bithoqoh Hawiyah adalah manifestasi serta alat kritik yang ditujukan kepada Israel. Mahmud terkenal sebagai sosok yang lantang bersuara serta diksi yang keras guna menyuarakan kritiknya dalam beberapa karyanya. Gayanya yang berapi-api namun (anehnya) terasa intim diciptakan untuk memancing respons langsung dari para pendengar (Said, 2019). Dengan itu, diksi yang digunakan tentunya mengandung falsafah kehidupan bangsa Arab yang dimanfaatkan sebagai landasan atau fondasi dari setiap aktivitas kehidupan. Bahwa teks sastra bisa didefinisikan sebagai struktur yang membawai nilai-nilai kultural yang memiliki kompleksitas akan signifikansinya. Oleh karena itu, pembaca karya sastra memiliki tugas untuk mampu menelaah lebih jauh kandungan dari isi dan bentuk suatu karya yang inheren dengan objek yang termuat dalam karya (Snir, 2017).

Sebagai pemaknaan atas pengalaman, karya sastra memiliki oportunitas yang mampu meleburkan antara yang fakta dengan fiksi, imajinasi akan dikerahkan untuk membentuk dunia metafisik. Begitu juga dengan keberadaan subjek, baik dalam karya maupun pengarangnya. Di sini, terlihat jelas bahwa potensi dari puisi ini sedikit banyaknya terinspirasi dari fenomena atau pergulatan diskursif yang dirasakannya langsung. Sebuah tindakan responsif ini merujuk pada tujuan penciptaan karya sastra sebagai bentuk kritik. Protes terhadap Israel yang memberlakukan orang Palestina sebagai orang-orang yang terbuang setelah tanah mereka direbut. Karena itu, tidak menutup 
kemungkinan bahwa dengan sastra, pengarang menyuarakan bentuk kritik agar seluruh bangsa Arab sadar akan ketertindasan yang sedang terjadi. Kesadaran kolektif demikian mengkonvergensikan pada posisi bahwa persatuan dan persaudaraan Arab adalah kunci utama untuk resistensi terhadap Israel. Karena itu, sesungguhnya bangsa Arab berpotensi untuk mencerna nilai-nilai atau ethics yang terumuskan dalam rasa persamaan kedaulatan sebagai bangsa.

Dua prinsip dari konsep potensialitas yang dirumuskan oleh Agamben bahwa makna pertama mengenai potensialitas adalah suatu pola, aktivitas, kemampuan yang tidak bisa direalisasikan pada masa lampau. Dan yang kedua bahwa potensialitas itu berdekatan dengan yang pertama, namun lebih ditekankan pada hal metafisik pada tindakan yang diasosiasikan dengan kebutuhan. Karena itu, potensialitas selalu berjalan dengan dua kaki, yakni yang berpotensi dengan yang tidak berpotensi. Artinya bahwa apa yang menjadi potensi sebagaimana adanya itu bukan sebagai yang natural, bahwa sesuatu mampu melampaui kondisi tersebut apabila dikaitkan dengan konsep yang kedua.

Puisi ini secara eksplisit juga mencerminkan kedua konsep dasar seperti di atas. Secara umum, bahwa sastra, terutama puisi, dalam diskursus Negara Timur Tengah merupakan entitas yang eksistensinya tidak hanya menawarkan estetikanya. Di sisi lain juga digunakan untuk memenuhi makna dalam proses signifikansi realita. Dengan itu, puisi ini merupakan wadah untuk menjadikan bangsa Arab mampu melampaui fanatisme yang mengakar kuat karena telah terfragmentasi oleh batas-batas kewilayahan. Serta menjadikannya sebagai mediator bahwa seluruh bangsa Arab harus mampu melampaui kondisi tersebut, karena naturalisasi merupakan keniscayaan, dan bahkan bangsa Arab mampu lebih progresif agar yang natural tidak menjadi yang alamiah. Oleh karena itu, apabila seluruh bangsa Arab memiliki persamaan identitas, maka mereka semua semestinya mampu menjadikan itu semua sebagai nilai etik yang diaplikasikan dalam bentuk nyata.

\section{Simpulan}

Potensialitas dalam karya sastra merupakan subjektivitas pengarang untuk memberitahukan bagaimana aktualisasi diri dalam realitas, dan juga menjadi impotensialitas dalam penangguhan diri. Hal ini dimaksudkan agar segalanya mampu diaktualisasikan dalam karya sastra, serta menjadi rambu-rambu dalam bentuk realitas faktual. Puisi Bithoqoh Hawiyah menunjukkan suatu potensialitas di dalam dan impotensialitasnya sebagai karya sastra. Puisi Bithoqoh Hawiyah menjadi potensialitas dalam mengukuhkan identitas kedaulatan Negara Arab untuk menegasikan konflik yang melanda dunia Arab. Sastra mewujudkan nilai positif dan bukan hanya penyalinan atau representasi dari keadaan faktual-empirik sebelumnya (Murray, 2011). Puisi Bithoqoh Hawiyah merupakan impotensialitas. Puisi ini memiliki kemampuan untuk melintasi jalur yang natural atau alamiah melampaui fungsi karya sastra itu sendiri. Bahwa ia adalah entitas yang memiliki dualitas dalam bekerja, yakni antara potensinya sebagai salah satu warisan peradaban bangsa Arab, kemudian impotensi kualitasnya berfungsi sebagai media kontemplasi dan kritik terhadap berbagai konflik sosial dengan motif meneguhkan serta menangguhkan eksistensi Palestina sebagai negara-banga yang merdeka. Dengan menggambarkan identitas dan karakter masyarakat Arab dimungkinkan untuk membangkitkan kesadaran intuitif seluruh bangsa Arab agar tidak larut dalam konflik yang melanda kawasan Timur Tengah, khususnya Palestina yang telah menelan banyak korban jiwa. 


\section{Daftar Rujukan}

Agamben, G. (1995). Idea of prose. SUNY Press.

Agamben, G. (1998). Homo Sacer: Sovereign power and bare life, trans. Daniel Heller.

Agamben, G. (1999). The man without content. Stanford University Press.

Agamben, G. (2020a). "What is an apparatus?" and other essays. Stanford University Press.

Agamben, G. (2020b). Creation and Anarchy. Stanford University Press.

Agamben, G., \& Heller-Roazen, D. (1999). Potentialities: Collected essays in philosophy. Stanford University Press.

Burdah, I., Ittihadiyyah, H., \& Yuwono, D. M. (2008). Konflik. Timur Tengah: aktor, isu, dan dimensi konflik. Pusat Studi Tengah dan Islam (PSTII), Fakultas Adab, UIN Sunan Kalijaga.

Dardiri, T. A. (2011). Perkembangan Puisi Arab Modern. Adabiyy t: Jurnal Bahasa Dan Sastra, 10(2), 283-308.

Epafras, L. C. (n.d.). Memahami ingatan kultural Yahudi dalam konflik IsraelPalestina. Jurnal Kawistara, 3(2).

Faruk, H. T. (2012). Metode penelitian sastra: sebuah penjelajahan awal. Pustaka Pelajar.

Foucault, M. (2007). Discipline and punish: The birth of the prison. Duke University Press.

Hitti, P. K. (2002). History of the Arabs. Macmillan International Higher Education.

Jung, D. (2004). The Middle East and Palestine: Global politics and regional conflict. Springer.

Kramer, M. (1993). Arab nationalism: mistaken identity. Daedalus, 122(3), 171-206.

Lechte, J. (2013). Agamben and the politics of human rights: Statelessness, images, violence. Edinburgh University Press.

Murray, A. (2011). Agamben dictionary. Edinburgh University Press.

Noor, Y. (2014). Sejarah Timur Tengah (Asia
Barat Daya). Yogyakarta: Ombak.

Nurjannah, E. P., \& Fakhruddin, M. (n.d.).

Deklarasi Balfour: Awal Mula Konflik

Israel Palestina. PERIODE: Jurnal Sejarah dan Pendidikan Sejarah. 1(1), 1526.

Putri, S. H. (2010). Tema Patriotisme dalam tiga puisi karya Mahmoed Darwish. (Skripsi). Universitas Indonesia, Jakarta.

Ritzer, G., \& Goodman, D. (2001). Postmodern social theory. In Handbook of sociological theory (pp. 151169). Springer.

Ross, A. (2008). The Agamben Effect.

Said, E. (2019). Imajinasi Intelektual. Terj. Nanda Akbar Ariefianto. Yogyakarta: Circa

Saleh, M. M. (2002). Palestina: sejarah, perkembangan dan konspirasi. Gema Insani.

Smart, J. R. (1996). Tradition and Modernity in Arabic Language and Literature. Psychology Press.

Snir, R. (2017). Modern Arabic Literature: A Theoretical Framework. Edinburgh University Press.

Sudibyo, A. (2019). Demokrasi dan Kedaruratan. Memahami Filsafat Politik. Giorgio Agamben. CV Marjin Kiri.

Tanaka, R. (1976). Systems models for literary macro-theory.

Watkin, W. (2010). The literary Agamben: Adventures in logopoiesis. Bloomsbury Publishing.

محمود درويش. 2013 ، أور/ق الزيتون، دار الناشر :

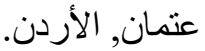


Jurnal Pendidikan Bahasa dan Sastra, Volume 21, Nomor 1, April 2021, pp. 51-66 